\title{
The South African FMCGs Use of Green Initiatives to Maintain Competitiveness and Sustainability Under the Global Coronavirus Pandemic
}

\author{
Kenneth Mathu \\ Department of Transport Economics and Logistics Management, Faculty of Economics and Management Sciences, North West University, \\ Mahikeng, South Africa
}

Email address:

kenmathu@yahoo.com,ken.mathu@nwu.ac.za

To cite this article:

Kenneth Mathu. The South African FMCGs Use of Green Initiatives to Maintain Competitiveness and Sustainability Under the Global Coronavirus Pandemic. Journal of Energy and Natural Resources. Vol. 9, No. 4, 2020, pp. 125-134. doi: 10.11648/j.jenr.20200904.14

Received: November 21, 2020; Accepted: December 4, 2020; Published: December 28, 2020

\begin{abstract}
The adoption of supply chain management (SCM) strategy by enterprises since mid-1980s has immensely transformed the flow of products/services from supply side to the ultimate customers on the demand side. The era has also experienced innovations in technology which has continued to fast track the implementation of supply chain efficiency and effectiveness. The unfolding implementation of the fourth industrial revolution (4IR) is hoped to spike the supply chain response time and render them more resilient and competitive. The study explored how fast moving consumer goods (FMCGs) suppliers and traders, utilised green initiatives or green supply chain management (GSCM), under the ravaging global Coronavirus pandemic to retain competitiveness and sustainability. The study was grounded in the theory of sustainable development and the sustainability theory in business. An exploratory qualitative research methodology and constructivism paradigm were used and non-probability sampling process applied. The participants were senior managers of FMCGs suppliers and traders who were interviewed telephonically, as it was during the partial lockdown period to control the spread of Coronavirus in countries around the globe including South Africa. The local and international supply chain networks were covered in the interviews as these organisations also traded in imported goods. The interviews were recoded, transcribed, coded and analysed via content analysis. The study outcome indicated that GSCM improved cost-effectiveness as enterprises were more resilient and used technology intensively to enhance information and product flow in the supply chain network that spiked the turnover and margins. The transportation optimisation saved costs and reverse logistics reduced waste and increased efficiency which enhanced competitiveness and sustainability. The supply chain resilience mitigated the disruption from Coronavirus pandemic.
\end{abstract}

Keywords: Competitiveness, Coronavirus, FMCGs, GSCM, SCM, Sustainability

\section{Introduction}

The enterprises have gone through tremendous transformation in the last four decades from the emergence of supply chain management (SCM) strategy and intensification of technology application [28]. The same period has seen the emergence of the global value chains (GVCs) from global manufacturing facilities that produce and supply products for the global markets. These manufacturing facilities receive raw materials from multiple suppliers and produce components and final outputs which are re-exported to various countries [49]. In the same era, China has positioned itself as the global manufacturing epicentre for industrial and consumer products for developed and developing countries [51]. These developments have transformed the consumer industry and broadened markets of goods/services as well as increased the risk factor in the supply chain.

Supply chain management (SCM) addresses the network of raw material suppliers, manufacturers and customers [30]. The supply chain network involves the supply of raw materials from upstream suppliers via inbound logistics process to the focal firm which transform raw materials into final products. The finished products are shipped downstream to distribution centres (DCs) that supply the retailers through 
outbound logistics process [7]. The focal firm also ship products via third-party logistics (3PL) to wholesalers/distributors that supply to smaller independent retail outlets [1]. These supply chain networks are vulnerable to disruptions such as the global lockdown imposed by nations for months in 2020 to slow down the spread of global Coronavirus also known as COVID-19 pandemic [50]. This has been a unique globalisation nightmare, more severe than the global financial crisis of 2008 [33]. As the world grappled with the impact of the disruptions, innovations in technology assisted with remote operations in most sectors of the society and business, culminating into a new normal of lean operations [26]. In business, these are the implications of green initiatives [45].

The global supply chain networks (SCNs) has to contend with complexities dealing with risk emanating from globalisation, ranging from demand and supply of products/services, logistics and rapid changes in technology among others [29]. Issues such as shortened product life cycles, outsourcing production and mixed mode of transportation posed logistics dilemma in international supply chain [12]. The American Production and Inventory Control Society (APICS) provided a broad based definition of supply chain risk as: "encompassing a variety of possible events and their outcomes that could have a negative effect on the flow of goods/services, funds or information resulting in some level of quantitative or qualitative loss for the supply chain" [1]. The quantitative loss entails loss that can be measured, while qualitative loss is descriptive and cannot be quantifiable.

The leading FMCGs suppliers and traders were interviewed telephonically on how they compete and remain in operations especially during the disruptions experienced in 2020 from global Coronavirus or COVID-19 pandemic. This was an exploratory research and qualitative research methodology and constructivism research paradigm were used. The study was grounded in the theory of sustainable development and sustainable theory in business.

\section{Theoretical Framework}

The theory of sustainable development (SD) and sustainability theory in business underpinned the study. The theory of sustainable development emerged from the United Nations 1987 Brundtland Report during the United Nations World Commission on Environmental and Development (UNWCED) conference. The theory states: "sustainable development is the development that meets the needs of the present without compromising the ability of the future generations to meet their own needs" [2]. In energy perspectives, the theory expresses the dilemma created by dependence on fossil-based energy sources that culminated into the prevailing phenomenon of climate change or global warming. Sustainable development ensues from "sources with long-term availability, dependable, safe and environmentally friendly" [10]. Energy is a major cost factor in manufacturing process, hence the need for renewable energy supply which is environmentally friendly as it has minimal carbon emissions [45]. Since the UNWCED conference in 1987, the development of energy from renewable sources has increased tremendously and the demand continues to grow [4].

The SD theory support enterprises' pursuit for environmental preservation through minimisation in the use of raw materials for production (dematerialisation), reduction of carbon emissions (decarbonisation) and managing industrial spillage of hazardous materials (detoxification) [45]. These are green initiatives that meet the long-term needs of customers without impacting negatively on the environment [44].

The sustainability theory in business cautions on "organisation's non-compliance with social norms and environmental requirements as it can be detrimental to its legitimacy and financial sustainability, and can be avoided by declaring their environmental policy to satisfy the society's demand" [24]. "The goal of a firm value creation can be achieved when management considers the interest of all stakeholders and integrates the five dimensions of sustainability performance into managerial strategies, actions and reporting" [34]. The five dimensions are economic, governance, social, ethical and environmental.

Streamlining FMCG suppliers require focusing on environmental, social and economic values referred to as triple-bottom line (TBL) [44]. The supply chain collaboration between suppliers and customers streamlines the logistics functions of the supply [45]. Those enterprises that focus on optimising returns with minimum resources are resilient and become competitive and sustainable [38]. The lessons learned by enterprises from Coronavirus pandemic indicated that being resilience enabled them to withstand and thrive the disruptions and retain competitiveness and sustainability.

\section{Literature Review}

The literature review focused on fast moving consumer goods (FMCGs) suppliers, supply chain management, green initiatives, supply chain resilience, global supply chain, supply chain disruption and technology use in supply chain. The lessons learned from the disruptions caused by Coronavirus pandemic on supply chains of FMCG suppliers and the mitigation measures undertaken.

\subsection{FMCGs Distribution Channels}

The fast moving consumer goods (FMCGs) distribution channels in South Africa has advanced since the inception of SCM in the mid-1980s to include modern shopping centres/malls as one stop centralised shopping [31]. The advancement of innovations in technology has added online shopping channel and further transformation in supply chain are anticipated with the implementation of the fourth industrial revolution (4IR) [48]. However, the traditional grocery stores still exist serving a sizeable market segment, mainly in less developed countries and they are mainly supplied by wholesalers who source from local and international suppliers mainly from China [30]. The extended 
supply chain has influenced growth of third-party logistics (3PL) service providers for transportation and warehousing to cater for the extended customer network. This study focused on these FMCGs supply chains that source locally and internationally.

After the outbreak of Coronavirus (COVID-19) pandemic, the FMCGs supply chains and other industries were shut down except those dealing with essential goods such as food and medical supplies. At the prime of the pandemic, the industries that were allowed to operate such as retailers operated with reduced workforce on site for few hours, while other employees worked remotely from home [39]. At the time of this research, most organisations continue to operate remotely.

The experience of globalisation enabled retailers to outsource finished goods and industries outsourced components, parts and equipment from international suppliers mainly from China [51]. As Coronavirus pandemic was global, the international supply chains were adversely affected and the recovery will take a long time. Most of the countries in the world experienced a period of lockdown at the peak of the first wave of the pandemic [50]. China offers the world numerous products in form of industrial equipment, semi-finished and finished products of high quality and at low prices. This has made China assume the role of the global manufacturing hub [18]. The retail chain stores, distributors and large wholesalers benefited from globalisation as they sourced products from countries like China where lower production costs made their products more competitive in other countries [42].

\subsection{Supply Chain Management (SCM)}

The Council of Supply Chain Management Professionals (CSCMP) defines SCM as:

"The integrated managing and control of the flow of information, materials and services from the suppliers of raw materials, through to the factories, warehouses and retailers, to the end customers. The benefits to the organization involved in supply chain management should be lower inventory costs, higher quality and higher customer-service levels. These benefits will only be gained, if all those involved in the supply chain are conforming to the standard set" [30].

The definition provides a holistic picture of the supply chain process from supply side, supplying raw materials to the focal company to manufacture to supply end products to the ultimate customers/consumers (demand side). The supply chain roles comprise: planning and forecasting, inventory management, logistics management, supply chain data management, demand management, replenishment services and supply planning [46]. This entails planning for the supply of raw materials, delivering raw materials for production of products which are distributed to the ultimate customers/consumers and ensuring the fulfilment of repeat orders or demand.

Green Supply Chain Management (GSCM)

Green supply chain management (GSCM) involves sharing of environmental responsibility with the value chain (VC) partners in purchasing, manufacturing, materials management, distribution and reverse logistics [47]. Value chain entails "the full range of activities that firms and workers do to bring a product from its conception to its end use and beyond" [20]. These activities comprised design, production, marketing, distribution and support to the final consumer. The principle of GSCM is expressed as the 'green initiatives' factors comprising of dematerialisation, detoxification and decarbonisation that streamline operations towards sustainability [45]. Dematerialisation entails reducing the amount of materials or time needed to produce and deliver products/services required by the customer. Detoxification entails reduction of pollutants from hazardous materials and industrial products. Decarbonisation or de-energisation refers to mitigation of carbon emissions in an organisation by using renewable energy and utilising processes with less carbon emissions.

The sharing of environmental responsibility entails utilisation of materials, products and processes which has less carbon emissions as it exacerbates the climate change or global warming [43]. Examples of GSCM applications include the use of renewable energy, bio-diesel for transportation, use of appropriate mode of transportation that reduces cost and/ or emissions reduction, use of full container load both ways where applicable and others [44].

Essentially, the green initiatives or green supply chain management facilitate optimisation in enterprises functions, reduction of waste and cost rendering the operation competitive, profitable and ability to continue or sustainable [40]. The GSCM is also described as a closed-loop supply chain as it is concerned with both forward and reverse movement of products [7]. In closed-loop supply chain, the emphasis is on reducing cost and capturing value as the ultimate goal of the manufacturer is for everything to be reused or recycled [16].

\subsection{Green Logistics Management}

Logistics management is a crucial component of SCM which is responsible for forward, reverse transportation and warehousing functions [47]. Logistics management is defined as "that part of supply chain process that plans, implements, and controls the efficient, effective flow and storage of goods, services, and related information from the point of origin to point of consumption in order to meet customer requirements" [1]. Reverse logistics is "the process of moving or transporting goods from their final forward destination for the purpose of capturing value" [7]. This involves sending new and used products back upstream for repair, reuse, recycling and refurbishing. The essence for the returned products is to scrap or salvage for resale.

The GCSM involves environmental considerations in purchasing, manufacturing, materials management, distribution and reverse logistics [45]. Thus, green logistics management pursues green initiatives through green transportation, green warehousing and green reverse logistics to drive sustainability in the supply chain [32].

The green logistics role is accomplished through logistics 
seven Rs (7Rs), translated as: "getting the right product to the right customer, in the right quantity, in the right condition, at the right place, at the right time, and at the right cost". The 7Rs eliminates waste which is a prerogative of green logistics to create value for the customer and render an enterprise more sustainable [6]. Pursuing a similar trend, green reverse logistics is concerned with returned materials that undergo through processes of recycling, reusing, refurbishing and disposal in landfill, reducing environmental pollution [44].

\subsection{Supply Chain Resilience}

Supply chain resilience is the ability of supply chain to respond to risk/disruption and recovering fast from these disruptions to return back to its original state better prepared to optimise customer service and financial stability [35]. The resiliency in supply chain was described as "the ability to return to a position of equilibrium after experiencing an event that causes operational results to deviate from expectations" [1]. This is what happened to enterprises in the period of global Coronavirus pandemic in 2020. [22] described supply chain resilience as "the ability to exploit the disruptions as a competitive advantage to excel over the competitors through redundancy, building flexibility and changing corporate culture".

Redundancy: Redundancy in supply chain requires holding higher level of inventory, maintaining low utilisation capacity and maintaining several suppliers that increases the operations cost. However, efficiency is achieved through utilisation of lean production processes.

Flexibility: Supply chain flexibility involves aligning procurement strategy with supplier relationship and adapting to postponement plans.

Cultural change: Stepping up communication with employees to condition them to familiarise with disruptions and be passionate about their work.

The period of supply chain disruptions in 2020 due to the global Coronavirus pandemic required resilience practice in enterprises to withstand unusual occurrence. Enterprises experienced redundancy with several employees losing jobs and bonded closely with the remaining employees most of whom worked remotely from home. As a result, flexibility ensued as enterprises repurposed and prioritised procurement of food and medical supplies as essential commodities [50].

This attribute of GSCM is lean as it is able to deliver products quickly to the end customers as it has streamlined procurement, quality and precision manufacturing, low level of inventory and use of consolidated transportation where multiple products use single shipment [25]. The lean supply chain controls seven types of waste, which are: overproduction, delays (process and parts), transportation, over-processing, inventory levels, motion (unnecessary movement of parts in production) and making defective parts [7].

\subsection{Supply Chain Risk/Disruption}

The words risk, disruption and vulnerability describe occurrences with negative consequences and they help describe such situations in supply chain. Their definitions in English Concise Dictionary assist in expressing the supply chain risk mitigation. Risk entails the possibility of incurring misfortune or loss; disruption is an interruption of progress of something; and vulnerability means exposure to attack.

i. Supply Chain Risk "comprises of a number of events and their outcomes that could have a negative effect on the flow of goods, services, funds or information resulting in some level of quantitative or qualitative loss for the supply chain" [41].

ii. Supply Chain Disruption are risk occurrences such as sudden fall in prices or natural disasters such as earthquakes, floods and disease pandemic [7].

iii.Supply Chain Vulnerability describes broader perspectives of risk embraced in SCM networks involving products/services, process performance, trading relationships, currency fluctuations among others [1].

In supply chain management, risk refers to a particular type of hazard or threat such as technological, political, terrorism and natural disasters among others. The supply chain risk also manifests as financial loss or competitive disadvantage resulting from a failure to implement 'best practice' in SCM [19].

The supply chain risk mitigation processes are as follows:

i. "Increasing Safety Stock and Forward Buying: It calls for extra expenses, but a crucial alternative as countries have experienced in beefing up medical equipment and food supplies during Covid-19 global pandemic.

ii. Identify Backup Suppliers and Logistics Services: Overdependence on China as key global supplier of general goods and the slowing down of logistics activities to contain the spread of the Covid-19 pandemic.

iii.Diversify Supply Base: The importance of multiple suppliers from geographically dispersed markets to minimise disruptions.

iv. Utilise Supply Chain IT System: The use of information technology (IT) enhance collection and sharing of crucial information with supply chain partners.

v. Develop a Formal Risk Management Programme: Helps identify potential disruptions and the appropriate response" [47].

The supply chain risk adversely impacts on enterprises financially, reputation and customer service among others [1]. As supply chains grow to include more international suppliers and customers, the complexity of disruption increases [47]. The Covid-19 pandemic of 2019/2020 exposed vulnerability and rendered many global organisations vulnerable. The South African FMCGs suppliers and traders are among the global enterprises which are heavily dependent on China for raw materials and finished products. The dominant role of China as a global manufacturing centre meant that any major global disruption like the novel Covid-19 pandemic which started in China's city of Wuhan in December 2019 put global supply chain at risk [49]. The leading role of China in global supply chain is 
demonstrated by those countries which were hardest hit by the pandemic and had China as their tier 1 (direct) or tier 2 (secondary) supplier [8]. In supply chain, tier 1 suppliers supply raw materials direct to the focal firm or manufacturer and tier 2 suppliers supply to tier 1 suppliers [7].

During the peak of the COVID-19 pandemic in 2020, a number of enterprises repurposed their activities to produce and supply the medical supplies such as ventilators and personal protection equipment (PPEs) for the healthcare workers and general public [23]. The disruptions contracted the South African gross domestic (GDP) 52\% annualised, with general industries including FMCGs decreasing by $67.6 \%$ during the peak period in the second quarter [27]. The Chinese economy which has been growing for over 40 years experienced $6.8 \%$ decrease in GDP in the first-quarter [5]. The United States retails sales dropped by $8.7 \%$ [9].

\subsection{Sustainability}

Sustainability is described as factors which enable enterprises to withstand, maintain or prolong existence [44]. These factors include the choice of renewable energy and the use of renewable raw materials that has minimal carbon emissions. Renewable energy is produced from natural sources such as solar, wind, hydro power and bio-diesel which has minimal carbon emissions. The renewable raw materials are those which produce products which at the end of life can be recycled or remanufactured into new products. Mitigating damage to the environment by reducing carbon emissions through logistics roles in sourcing, transportation and warehousing are green initiatives which render enterprises sustainable [45]. This entails sourcing from suppliers who use renewable raw materials, practice ethical labour standards and use transportation that minimise carbon emissions [13].

Sustainability is defined as "the ability to meet needs of the current supply chain members without hindering the ability to meet the needs of future generations in terms of economic, environmental and social challenges" [47 \& 2]. The enterprise's accountability of economic, environment and social are sustainability attributes, referred to as 'triplebottom line' (TBL). This happens when there is close working relationship between the enterprise, suppliers and other role players or collaboration of all the parties involved in the supply chain [44]. The enterprise's drive to optimise returns with minimum resources results in competitiveness and sustainability [45].

\subsection{Environmental Concerns}

Environmental concerns refer to cognition in the use of green products for protection of the environment [44]. Environmental protection is stipulated in the biosphere rules that enterprises are required to pursue to avoid environmental degradation. The biosphere is the earth's surface and atmosphere inhabited by living things which is also the environment in which enterprises operate [45]. The book "Earth Incorporated" described five rules or principles of biosphere as materials parsimony, power autonomy, value cycles, sustainable product platforms and function over form [44].

i. "Materials parsimony: The focus is on the need to minimise the types of materials used in products especially those which are life-friendly and economically recyclable. In implementing this rule, an enterprise would realise reduced supplier complexity, reduced production complexity, reduced toxic risk, reduced compliance costs, volume purchase discount, improved health and safety, improved work productivity, improved products attributes and improved environmental performance.

ii. Power Autonomy: To reduce energy costs with the use of renewable energy for production processes.

iii. Value cycle: Involves product recovery from recycling and remanufacturing as a value-added process.

iv. Sustainable product platforms: Benchmarking to improve product benefits in scale and scope and gain knowledge and experience by doing.

v. Function over form: Fulfil customer functional needs in ways that sustain value cycle".

\subsection{Towards a Sustainable Enterprise}

The following are some crucial factors pursued in realisation of a sustainable enterprise:

1. "Involvement of all value chain partners.

2. A strategic plan to be prepared and pursued.

3. Highlighting awareness of climate change (reduction of carbon emissions, energy efficiency and so on)

4. Waste must be recycled, reused and reduced

5. Intensify use of natural resources such as water and renewable sources of energy

6. Enforce supplier ethical assessment and collaboration" [44]

These activities streamline enterprises making them to undertake only the crucial functions, minimising resources through reuse and recycling and intensify use of natural resources such as water and renewable energy that has less carbon emissions. These are risk mitigation processes that make enterprises more sustainable and more competitive through cost saving, business differentiation and attracting more customers [13].

\subsection{Technology Use in Supply Chain Management}

In dealing with both local and international suppliers, enterprises are aided by technology to enhance communication to speed up the product flow [14]. The distribution operations provide supply chain capabilities such as cost-reducing opportunities in limiting product handling, consolidating facilities and streamlining inventories [3]. Limiting product handling in this study refers to a focus on food products FMCGs that supply the distributors/wholesalers that supply the independent mediumsized retailers. Consolidating facilities entails managing the 
distributors/wholesalers floor area and the equipment used there. Streamlining inventories involves orderly product arrangement for fast picking, packaging and dispatch [25].

Technology is an enabler of supply chain management as it integrates the supply chain partners for faster transactions and provides visibility of processes at various stages in the supply chain [11]. The global implementation of the fourth industrial revolution (4IR) is hoped to speed up SCM processes, render them agile, focused and more sustainable [48]. At the moment, computers are used in most enterprises to connect with the world wide web for internet access. Some of the technology applications comprises the following:

i. Electronic data interchange (EDI): A computer to computer exchange of business documents such as purchase orders, order status enquiries, reports, promotion announcements, shipping and billing notices [19].

ii. Barcode: A series of alternating bars and spaces printed or stamped on parts, containers, or labels representing encoded information that can be read by electronic readers. It is used for timely and accurate input to a computer system [1].

iii.Radio frequency identification (RFID): A WI-FIenabled radio frequency identification tags to allow tracing of items in real time.

iv. Warehouse management systems (WMS): A software control system that improves product movement and storage operations through efficient management of information and completion of distribution tasks [21].

v. Transport management systems (TMS): A computer application system that is designed for the management of transportation using modules that focus on specific functions such as intermodal transportation, fleet service management, load planning and optimisation among others [1].

vi. Global positioning systems (GPS): It is used for tracking vehicles such as the delivery trucks [1].

\section{Problem Statement}

The practice of supply chain management in enterprises has revolutionised the management through intensified technology application with more emphasis on customer focus [19]. The FMCGs suppliers operates in a very competitive market which prompts the need for the exploration of green initiatives in supply chain management which enhanced the flow of information and products that spiked turnover and margins, improving their competitiveness and sustainability. With supply chain disruption due to Coronavirus pandemic, there is need to explore how GSCM enabled FMCGs to withstand the disruption and retain competitiveness and sustainability.

\subsection{Primary Objective}

The primary objective of the study was to establish how green supply chain management enhanced competitiveness and sustainability of FMCGs suppliers and how these enterprises were able to withstand the disruption caused by Coronavirus global pandemic.

\subsection{Empirical Objectives}

Three empirical objectives were pursued as follows: to establish risk mitigation enhanced competitiveness and sustainability of FMCGs supply chains as follows:

1. Establishing that intensive technology use in GSCM enhanced information and product flow in FMCGs enterprises spiking turnover and margins.

2. Establishing that transport optimisation in GSCM reduced cost and improved efficiency of FMCGs enterprises.

3. Establishing that reverse logistics in GSCM recovered value and reduced waste in FMCGs enterprises.

4. Establishing that supply chain resilience mitigated the supply chain disruption caused by the Coronavirus pandemic in 2020 .

\subsection{Methodology and Design}

This study pursued a qualitative research methodology and constructivism research paradigm to establish that green supply chain management (GSCM) enhanced competitiveness and sustainability of fast moving consumer goods (FMCGs) suppliers and traders in South Africa. Constructivism like qualitative research is the process through which interviews are conducted with participants to generate research data [17]. The data for this study was collected through telephonic interviews with supply chain and procurement managers of leading manufacturers of FMCGs and traders who trade in locally produced and imported commodities. This mode of interview took place during the level 2 lockdown period when social distancing was still enforced by the government in the fight against Covid-19 pandemic.

Research design is described as the framework of the study on how to generate empirical evidence to examine the research questions [37]. The empirical evidence was derived from data obtained from telephonic interviews conducted with FMCGs suppliers and traders in South Africa. This mode of interview was used as South Africa and most other countries in the world reeled from Coronavirus pandemic and not fully open for trading.

The theory of sustainable development and sustainable theory in business underpinned the study. These two theories emphasis on reduced use of resources and renewable energy that has limited carbon emissions which are characteristics of green supply chain management. It was also important to focus on energy consumption as it was one of the leading cost components in enterprises' operations. The green logistics provided streamlined green warehousing with elaborate warehouse management systems that provided operational effectiveness and green transportation with elaborate time scheduling and practised full-load capacity deliveries. The returned products were refurbished and recycled for reuse, which recovered value for the enterprise. The process 
significantly contributed towards an enterprise's efficiency, competitiveness and sustainability [6].

The sample size of the study comprised 15 supply chain and procurement managers drawn from five FMCGs suppliers, five wholesalers/traders and five retailers. The selected participants were approached directly via e-mail and telephone to arrange for telephonic interviews. They were introduced to the value proposition of the study which was "to establish how green supply chain management enhanced competitiveness and sustainability of FMCGs suppliers". The interview duration of 10-15 minutes was agreed and that it was to be recorded with a digital voice recorder. The participants were assured of confidentiality, anonymity and non-disclosure of their identity as research ethics dictate [15].

The recorded interviews were subsequently transcribed, interpreted, coded and analysed via content analysis as prescribed in [37]. The themes that emerged were classified as major themes and sub-themes and they were used in establishing the outcome of the study.

\section{Results and Discussion}

After data interpretation, twelve major themes and a number of minor themes emerged that helped in establishing the results of the study. The major themes featured Coronavirus pandemic, supply chain disruption, technology role, supplier/customer relationship, raw materials/production/inventory, lost jobs, medical/food supplies, Chinese imports, international travel/transportation, local transportation, warehousing and reverse logistics. Some of the sub-themes comprised of closed businesses, reduced economic activity, personal protection equipment (PPE), limited transportation, storage space, customers service and repurposed suppliers among others. These themes highlighted the global connectedness through globalisation and the crucial role played by China in the global supply chain network.

The massive supply of raw materials, components and finished general goods from China to all nations has positioned the country as the global manufacturing centre [8]. The global pandemic of Coronavirus started in Wuhan city in China in late 2019 and spontaneously spread globally in 2020 causing disruption and destruction of human lives and businesses of a magnitude not experienced in modern history [50]. All enterprises were influenced and impacted by the Coronavirus pandemic, hence the reason to feature it in the study. The lessons from the Coronavirus pandemic immensely influenced competitiveness and sustainability of FMCG suppliers through resilience and stringent green initiatives as determined by the three empirical objectives of the study.

The three empirical objectives were achieved as corroborated by the themes that emerged and the evidence from the participants expressed herewith:

i. Empirical objective 1: "Establishing that intensive technology use in GSCM enhanced information and product flow in FMCGs enterprises spiking turnover and margins." -Objective achieved

The adoption of supply chain management coincided with the innovations in technology which is an enabler of SCM in enhancing the flow of information and products in the supply chain network. Streamlining conventional SCM with green initiatives requires integration among the supply chain partners to speed up information and product flow that provide continuity of supplies. This continuous flow of products enables the continuity of the FMCG enterprises which increased turnover and margins. This is a competitive advantage that drive the competitiveness and sustainability of the enterprise. During the Coronavirus pandemic most businesses closed down, while others scaled down with many jobs lost and other employees working remotely from their homes connected via internet. That was a new lesson on the crucial role of technology and ushered in the future outreach of the fourth industrial revolution (4IR).

Their views were summed up by remarks of participant 3 :

"The Covid-19 or the Coronavirus pandemic brought sufferings to people and businesses. A number of small enterprises has closed down and the larger ones will take years to recover from loses that has left thousands of employees without jobs. Some organisations repurposed to produce and supply medical supplies in assisting the government's campaign to stop the spread of the virus. Thanks to technology as many institutions and companies continued to work remotely with reduced employees. We had to rely internet to place orders with long lead time as local and international travels and shipment were limited to essential medical and food supplies".

ii. Empirical objective 2: "Establishing that transport optimisation in GSCM reduced cost and improved efficiency of FMCGs enterprises" - Objective achieved

The enterprise's efficiency is linked to supplier-customer collaboration which enabled timeous supplies and streamlined the retailers' shared 3PL transportation that resulted in cost saving in operations. The participants expressed this as a relationship built over a long period of time which benefited both parties. Transport optimisation by FMCG suppliers and retailers was crucial especially during the Coronavirus pandemic. There were limited travel and transportation allowed, hence sharing full-load shipments and planned routes was the appropriate as it was efficient and reduced cost of the limited available business at that time. This was summed up by the remarks of participant 11 as follows:

"Transportation is one of the major cost elements in our business. In normal time we have always outsourced 3PL firms and it became even more important during the Covid-19 lockdown when movement of people and goods was limited to essential services in food and medical supplies. Sharing transportation in full-load shipments and timely scheduling is what we do. We imported a lot of finished products from China and it was a nightmare to have a shipment arrive in our ports with limited operations and the same situation applied to inland transportation before the current improved situation. We were contracted to import medical supplies from China outside our line of business to assist the government fight against the spread of Coronavirus. Outsourcing and sharing transportation reduced costs and continue to be more efficient 
for our business".

iii.Empirical objective 3: "Establishing that reverse logistics in GSCM recovered value and reduced waste in FMCGs enterprises" - Objective achieved

The green logistics has value-adding activities in utilising shared 3PL transportation and reorganised warehousing using information system for internet connection through computers to place orders and management of inventories. The supplier-customer collaboration and ease of transactions through IT use streamlined operations. A sustainable enterprise becomes more competitive through cost saving, business differentiation and attracting more customers [13]. These activities as in objective one and two rendered the enterprise more competitive and reduced waste rendering a clean environmental. The reduction of waste and operating costs improved the enterprise's stability and sustainability. This concurs with the remarks of participant 14:

"As FMCGs has a thin profit margin, saving on transportation is very important to reduce our operating costs. Replacement of damaged products added value which improved our margins and reduced waste that could pollute the environment. The process improved our competitiveness and ability to continue in business - sustainability

iv. Empirical objective 4: "Supply chain resilience mitigated the supply chain disruption caused by the global Coronavirus pandemic in 2020" - Objective achieved

The global Coronavirus pandemic disrupted every institution and businesses in most countries globally. Some countries managed to control the pandemic in few months, but a number of them are still battling the pandemic and the impact. One lesson learned from the pandemic is to withstand the disruptions by being resilient. That means ability to thrive in disruptions and emerge more stable to optimise customer service and earning potential [35]. Resilience demands reorganisation, flexibility and redundancy as experienced with organisations taking lean strategy and laying off several employees, while the core workers continued working remotely via internet connectivity. The organisations that failed to adhere to these factors has perished, while the resilient ones are rebuilding and reabsorbing the employees who had become redundant. This summarised by the remarks of participants 8 :

"After the lockdown, a number of employees became redundant and we maintained contacts remotely with the core employees from all departments as we assessed the situation. After few days some orders had to be dispatched and it was possible to coordinate remotely and execute. We became lean and flexible and were able to respond when the authority required our interventions to produce and sometimes import rare components. Our operations have resumed about $70 \%$ of our normal capacity and the demand projections in medium-term are higher than before the Coronavirus outbreak"

\section{Conclusion}

The study explored the contributions of GSCM to competitiveness and sustainability of FMCGs suppliers and traders under Coronavirus pandemic in South Africa in 2020. The exploration covered the FMCG suppliers and traders who deal in local and imported commodities, role of green initiatives, global Coronavirus pandemic and disruptions, supply chain resilience, sustainability and technology use in supply chain. The theory of sustainable development and sustainable theory in in business that underpinned the study were discussed. An exploratory qualitative research methodology and the constructivism research paradigm were described. As the study was undertaken during lockdown level 2 in South Africa, the interview process which was telephonic was expressed.

The four empirical objectives set for the study were established and covered exhaustively in the outcome of the study. The outcome of the study was determined from twelve major themes and a number of minor themes that emanated from the study. The outcome that green initiatives in SCM enhanced competitiveness and sustainability of FMCGs suppliers and traders was exhaustively covered in the results. The lessons learned from Coronavirus pandemic featured prominently in the results and the need for organisations' resilience to thrive in disruptions and excel afterwards were elaborated.

\subsection{Managerial Implications}

The study has strong managerial implications of conventional SCM strategy transforming through green initiatives into GSCM which is leaner, more competitive and sustainable. The green logistics management that drives transport optimisation and streamlined warehouse management using technology. The positive contribution of GSCM to the environment in form of reverse logistics management processes of return, refurbishing and recycling that reduce waste and recover value. The highlight of managerial implications in the study involves managing through Coronavirus pandemic through mitigation of risk/disruption driven by resilience. These types of management rendered and retained the FMCG suppliers' competitiveness and sustainability.

\subsection{Recommendations}

The study focused on the FMCGs suppliers in South Africa during the Coronavirus pandemic. A more representative study is recommended covering wider scope of industries providing products and service during and after the Covid-19 disruptions. The study would compare parameters of resilience across diverse industry sectors.

\section{References}

[1] APICS Dictionary. 2013. Supply Chain Dictionary. $14^{\text {th }}$ ed. Chicago, IL: APICS Publishing.

[2] BRUNDTLAND, G. H. (1987). United Nations Report on sustainable development. [Online]. Available at: https://www.britannica.com/topic/Brundtland-Report. Accessed on 2020-04-03. 
[3] CADWELL. 2018. Stockless inventory: Getting more with less. [Online]. Available at: http://www.jhconline.com/stockless-inventory-getting-morewith-less.html; Accessed on 2020-04-02.

[4] CENTER FOR CLIMATE AND ENERGY SOLUTIONS. 2018. Renewable energy and supply and demand. [Online]. Available at: https://www.c2es.org/content/renewable-energy/. Accessed on 2020-09-08.

[5] CHOO, J, OI. J., THOMAS, C. \& WU, X. 2020. After COVID-19: Rebooting business in China. [Online]. Available at: https://thediplomat.com/2020/07/after-covid-19-rebootingbusiness-in-china/. Accessed on 2020-09-09.

[6] CHRISTOPHER M. 2016. Logistics \& Supply Chain Management. $5^{\text {th }}$ edition. E-book. Pearson. [Online]: https://www.bookdepository.com/Logistics-Supply-ChainManagement-Martin-Christopher/9781292083797. Accessed on 2020-02-02.

[7] COYLE JJ, LANGLEY CJ, NOVACK RA \& GIBSON BJ. 2017. Supply Chain Management: A Logistics Perspective. $10^{\text {th }}$ ed. Boston, MA: Cengage Learning.

[8] DELOITTE CANADA. 2020. When China, the world's factory, is impacted, global supply chains are impacted. [Online]. Available at: file:///C:/Users/35565039/AppData/Local/Temp/sea-about-covid19-managing-supply-chain-risk-disruption.pdf. Accessed on 202009-06.

[9] DOW JONES. 2020. U.S. retail sales plummet. [Online]. Available at: https://fmstatic.cnbc.com/awsmedia/chart/2020/04/15/retailsales. 158695 4228961.png?. Accessed 2020-09-09.

[10] EPSTEIN, M. J. \& BUHOVAC, A. R. 2014. Making Sustainability Work: Best Practices in Managing and Measuring Sustainability. San Francisco, CA: Berrett-Koehler.

[11] FAWCETT, S. E. 2011. Information technology as an enabler of supply chain collaboration. Journal of Supply Chain Management, 47 (1): 38-59.

[12] FAWCETT, S. E., MAGNAN, G. M. \& MCCARTER, M. W. 2008. Supply chain alliances and social dilemmas: Bridging the barriers that impede collaboration. International Journal of Procurement Management, 1 (3): 318-341. DOI: 10.1504/IJPM.2008.017528. Accessed on 2020-09-09.

[13] HARRISON, A., van HOEK, R. \& SKIPWORTH, H. 2014. Logistics Management and Strategy: Competing Through The Supply Chain. Harlow, UK: Pearson Education.

[14] HOFMANN, P. \& REINER, G. 2006. Drivers of improving supply chain performance: An empirical study. International Journal of Integrated Supply Management, 2 (3): 214-230. DOI: 10.1504/IJISM.2006.0088594. Accessed on 2020-09-09.

[15] KUMAR, R. 2005. Research Methodology: A step by step guide for beginners. $2^{\text {nd }}$ ed. London: Sage.

[16] KUMAR, N. R. \& SATHEESH KUMAR. 2013. Closed loop supply chain management and reverse logistics - A literature review. International Journal of Engineering Research and Technology, pp. 455-468.

[17] LEE N \& LINGS I. 2008. Doing Business Research: A Guide to Theory and Practice. London: Sage.

[18] MADE-IN-CHINA NEWS. 2020. Supply chain needs to go.
[Online].

Available

at:

https://www.foxbusiness.com/markets/coronavirus-made-inchina-supply-chain. Accessed on 2020-09-06.

[19] MANGAN, J., LALWANI, C., BUTCHER, T. \& JAVADPOUR, R. 2012. Global Logistics \& Supply Chain Management $2^{\text {nd }}$ ed. West Sussex, UK: John Wiley.

[20] MAYER, F. W., PHILliPS, N. \& POSTHUMA, A. C. 2017. The political economy of governance in a 'global value chain world'. Journal of New Political Economy, 22 (2): 129-133.

[21] MCCREA B. 2018. Warehouse management systems (WMS)/Inventory management technology: 6 trends for modern age. Logistics Management. [Online]. Available at: www.logisticsmgmt.com/article/warehouse

management_wms_inventory_management_technology_6_tre nds_for_the_m. Accessed on 2020-04-07.

[22] MICHELMAN, P. 2007. Building a resilient supply chain. Business Review. [Online]. Available at: https://hbr.org/2007/08/building-a-resilient-supplych\%20May\%2011. Accessed on 2020-08-30.

[23] MILLER, N. 2020. How factories change production to quickly fight Coronavirus. [Online]. Available at: https://www.bbc.com/worklife/article/20200413-howfactories-change-production-to-quickly-fight-coronavirus. Accessed on 2020-09-06.

[24] MOUSA, G. A. \& HASSAN, N. T. 2015. Legitimacy theory and environmental practices: Short notes. International Journal of Business and Statistics Analysis, 2 (1): 41-53.

[25] MURRAY M. 2019. Creating a lean supply chain. The Balance Small Business. [Online]. Available at: https://www.thebalancesmb.com/lean-supply-chainmanagement-2221274. Accessed on 2020-09-04.

[26] MYERSON, P. 2016. Supply chain technology brings the world closer together. [Online]. Available at: $\mathrm{https}$ ://www.industryweek.com/supply-

chain/article/22008073/supply-chain-technology-brings-theworld-closer-together. Accessed on 2020-09-06.

[27] NAGARAJAN, S. 2020. South Africa's GDP plunges over $50 \%$ as COVID-19's 'punch in the gut' triggers the steepest decline since 1960. [Online]. Available at: https://markets.businessinsider.com/news/stocks/south-africagdp-plunges-in-steepest-decline-1960-2020-9-1029570054\#. Accessed on 2020-09-09.

[28] OSTIDICK, N. 2017. How technology is reshaping today's supply chain. The Supply Chain Manager's Guide to Industry 4.0. [Online]. Available at: https://blog.flexis.com/howtechnology-is-reshaping-todays-supply-chain. Accessed on 2020-09-06.

[29] PETERSEN. T. 2017. What are the drivers behind economic globalisation? [Online]. Available at: https:/gedproject.de/globalization/what-are-the-drivers-behindeconomic-globalization/. Accessed on 2020-09-09.

[30] PIENAAR, W. J. \& VOGT, J. J. 2012. Business Logistics Management: A Value Chain Perspective. Cape Town: Oxford University Press.

[31] PRINSLOO, D. A. 2010. Classification and hierarchy of retail facilities in South Africa. [Online]. Available at: http://urbanstudies.co.za/wp-content/uploads/2016/07/NewRetail-Classification-20101.pdf. Accessed on 2020-04-09. 
[32] QRUNFLESH, S. \& TARAFDAR, M. 2013. Lean and agile supply chain strategies and supply chain responsiveness: the role of strategic supplier partnership and postponement. Emerald Insight, 18 (6). [Online]. Available at: https://www.emerald.com/insight/content/doi/10.1108/SCM01-2013-0015/full/html. Accessed on 2020-09-06.

[33] RAZIN, A. 2010. Global financial crisis 2008 and beyond: A rude awakening. [Online]. Available at: https://www.researchgate.net/publication/256042526_Global_ Financial_Crisis_2008_and_Beyond_A_Rude_Awakening. Accessed on 2020-09-06.

[34] REZAEE, Z. 2016. Business sustainability research: A theoretical and integrated perspective. Journal of Accounting Literature, pp. 48-64.

[35] RIBEIRO, J. R. \& BARBOSA-POVOA, A. P. 2018. Supply chain resilience: Definitions and modelling approaches - a literature review. [Online]. Available at: https://www.researchgate.net/publication/320901897_Supply_ Chain Resilience Definitions and Quantitative Modelling Approaches_-_a_literature_review. Accessed on 2020-09-06.

[36] ROBINSON CH. 2018. Retail consolidation: Your answer to reducing complexity in retail deliveries. [Online]. Available at://blog.chrobinson.com/freight-services/retail-consolidationanswer-reducing-complexity-retail-deliveries/; downloaded on 18 November 2018.]

[37] SAUNDERS M, LEWIS P \& THORNHILL A. 2016. Research Methods for Business Students. $7^{\text {th }}$ edition. Harlow, UK: Pearson Education.

[38] SHEFFI, Y. 2013. The resilient enterprise: Overcoming vulnerability for competitive advantage. ResearchGate. [Online]. Available https://www.researchgate.net/publication/23573710_The_Resi lient Enterprise Overcoming Vulnerability for_Competitive _Advantage. Accessed on 2020-09-09.

[39] STATISTICS SOUTH AFRICA. 2020. Stats SA warns of business closures due toCOVID-19 lockdown. [Online]. Available at: https://www.iol.co.za/news/politics/stats-sawarns-of-business-closures-due-to-covid-19-lockdown46982429. Accessed on 2020-09-06.

[40] SWENSON, B. 2020. 10 Steps of reducing costs while saving the environment. Allbusiness.com [Online]. Available at: https://www.allbusiness.com/10-steps-to-reducing-costswhile-saving-the-environment-7310546-1.html. Accessed on 2020-08-23.

[41] TRENT, R. J. \& ROBERTS, L. R. 2010. Managing Global
Supply and Risk: Best Practices, Concepts and Strategies. Fort Lauderdale, FL: J. Ross Publishing.

[42] UKEssays. 2017. Manufacturer to wholesaler to retailer to consumer. [Online]. Available at: https:/www.ukessays.com/essays/marketing/manufactureragent-wholesaler-retailer-consumer-marketing-essay.php. Accessed on 2020-04-09.

[43] UNITED NATIONS FRAMEWORK CONVENTION ON CLIMATE CHANGE (UNFCCC). 2010. Cancun climate change conference - November. [Online]. Available at: https://unfccc.int/process-and-meetings/conferences/pastconferences/cancun-climate-change-conference-november2010/cancun-climate-change-conference-november-2010-0. Accessed on 2020-04-12.

[44] UNRUH, G. 2010. Earth, INC. Boston, MA: Harvard Business Press.

[45] WANG, H-F \& GUPTA, S. M. 2011. Green Supply Chain Management: Product Life Cycle Approach. New York: McGraw Hill.

[46] WHITE D \& MOHDZAIN MB. 2009. An innovative model of supply chain management: A single case study in electronic sector. International Journal of Information Technology and Management 8 (1): 69-84.

[47] WISNER, J. D., TAN, K-H. \& LEONG, G. K. 2016. Principles of Supply Chain Management "A Balanced Approach". $4^{\text {th }}$ ed. Boston, MA: Cengage Learning.

[48] WORLD ECONOMIC FORUM. 2017. Impact of the fourth industrial revolution on supply chains. [Online]. Available at: http://www3.weforum.org/docs/WEF Impact of the Fourth Industrial_Revolution_on_Supply_Chains_pde. $\overline{d f}$ Accessed on 2020-04-09.

[49] WORLD ECONOMIC FORUM (WEF). 2020. COVID-19 implications on manufacturing and supply systems. [Online]. Available at: https://www.weforum.org/projects/reshapingglobal-value. Accessed on 2020-09-06.

[50] WORLD HEALTH ORGANIZATION (WHO). 2020. COVID-19 - a global pandemic. [Online]. Available at: https://africacheck.org/fbcheck/yes-world-health-organizationdeclared-covid-19-coronavirus-outbreak-a-pandemic/. Accessed on 2020-09-06.

[51] WORLD TRADE ORGANIZATION (WTO). 2020. Trade set to plunge as COVID-19 pandemic upends global economy. [Online]. Available https://www.wto.org/english/news_e/pres20_e/pr855_e.htm. Accessed on 2020-09-06. 